\title{
Migration, Informalization and Public Space in Santa Cruz, Bolivia
}

Joshua Kirshner

Cornell University

\begin{abstract}
In this paper, I ask how migrant insertion into the local economy, in particular into the informal economy, has led to contestation over public space in Santa Cruz. Related to this issue, the paper asks what sorts of collective actions are used to defend rights to the use of urban public space, and what are the key points of contention. In my analysis, I look at theoretical connections between the informal economy and urban space, recent changes in the Santa Cruz local economy -including accelerated migration and the burgeoning informal economy- and conflicts over uses of public urban space.
\end{abstract}

Keywords

Andean Migration to Santa Cruz, Camba Nation, Cívic Committee of Santa Cruz, Guild Associations, Informal Economy, Urban Space, Territorial Control 


\section{REVISTA DE ESTUDIOS BOLIVIANOS}

\section{Resumen}

En este trabajo indago cómo la inserción migratoria en la economía local, particularmente en la economía informal, ha llevado a un debate sobre los usos del espacio público en Santa Cruz. En relación con esta problemática, mi trabajo explora qué tipo de acciones colectivas se utilizan para defender los derechos del uso del espacio público urbano, y cuáles son los puntos claves de conflicto. En mi análisis, exploro las conexiones teóricas entre la economía informal y el espacio urbano, los cambios recientes en la economía local de Santa Cruz -incluyendo la migración acelerada y la emergente economía informal- y los conflictos sobre usos del espacio urbano público.

Palabras claves

Asociaciones gremiales, Comité Cívico de Santa Cruz, Control Territorial del Espacio Urbano, Economía Informal, Migración Andina a Santa Cruz, Nación Camba

\section{Introduction}

This paper explores the intersections between migration, the informal economy and conflicts over uses of public space in Santa Cruz de la Sierra, Bolivia, as a window into the dynamics of highland migrant integration and exclusion in this city, and the forces shaping them. Once an isolated frontier town, Santa Cruz benefited from state investment policies beginning in the 1950s with the MNR government's "March to the East" program. This program sought to incorporate the eastern lowlands into the national economy. By the 1990s, Santa Cruz had overtaken La Paz as Bolivia's financial capital and most important economic pole, and its political influence is on the rise. Regional economic growth, along with state-sponsored resettlement plans, has attracted labor migration from poorer Andean regions over the past four decades. Santa Cruz is now one of Bolivia's fastest growing metropolitan areas. It is also the center of a growing regionalist movement, expressed 


\section{REVISTA DE ESTUDIOS BOLIVIANOS}

in claims of political autonomy as a means for regional governments to play a greater role in public decision-making, including a strong element of place-based identity.

In this paper, I ask how migrant insertion into the local economy, in particular in the informal economy, has led to contestation over public space in Santa Cruz. Related to this issue, what sorts of collective actions are used to defend rights to the use of urban public space, and what are the key points of contention? To approach these questions, I explore theoretical connections between the informal economy and urban space. I then examine recent changes in the Santa Cruz local economy, including accelerated in-migration and the burgeoning informal economy, and I argue that these trends are producing particular patterns of urban growth and altering the urban landscape. Finally, I turn to conflicts over uses of public space, analyze local planning policies to reorganize market networks, and consider how competing perceptions and reactions to these policies reflect unresolved tensions in local development, urban growth, and migrant integration.

In this analysis, I argue that the organizations charged with managing urban growth and development-municipal officials and planners-and traditionally powerful Santa Cruz civic institutions, such as the Comité Cívico and the Cámara de Industria, Comercio, Servicios y Turismo (CAINCO) [Civic Committee and the Chamber of Commerce] attempt to regulate the most visible aspects of the informal economy through a new municipal plan to reorganize market networks. I also suggest that these groups seek to break up the power of informal vendor associations or gremios through the municipal plan, by reorganizing the largest markets and relocating the vendors.

Traditional Santa Cruz civic groups have witnessed the rise of new forms of commerce, services, and finance in the city over the past two decades from diverse origins. While traditional elites and local officials recognize informal commerce as an important "safety net" for the poor, they view the gremio associations and the vendors they represent as threatening to their notion of what belongs in urban public space, and stigmatize them as out of place and provoking urban disorder.

Methodologically, I pursued several avenues of inquiry to examine these questions. To investigate recent shifts in the local economy, I gathered data from the 2001 national census and the Plan de Ordenamiento Territorial (PLOT), a recent comprehensive plan for the city 


\section{REVISTA DE ESTUDIOS BOLIVIANOS}

of Santa Cruz (Gobierno Municipal de Santa Cruz de la Sierra, 2004a). To uncover conceptions of public space, I reviewed recent municipal ordinances on uses of public space (GMSC 2004b), and a report on the new municipal plan for markets (Salek 2007a). I interviewed leaders of gremio associations representing informal vendors, local government officials, including planners and economic development officials, and two city council members (one current and one former member) who also hold positions as leaders of gremio federations. Finally, I visited the four largest municipal markets and observed interactions among vendors, and between vendors and customers, and I organized two group interviews with 30-35 members of two different gremios in Los Pozos, the city's second largest market. ${ }^{1}$

To narrow the scope of the study, I focused on informal commerce, including market and street vendors, as one type of activity in a much broader informal economy. I chose market and street vending because it is a highly visible occupation and one that has grown considerably with the arrival of Andean migrants to Santa Cruz. Furthermore, it features strong forms of collective organization, and it has become the target of municipal policies aimed at regulating informal activities in public spaces more broadly. In this sense, market vendors have become a flashpoint for issues surrounding the informal economy, in-migration, and demographic change.

My analysis contributes to recent discussions on the spatial dimensions of social exclusion and struggles over the access to and meanings surrounding urban space in local contexts (Kudva, Madanipour). It also raises larger questions regarding processes of informalization and reformalization, and the spatial implications and political challenges of regulating informal economic activities. Similarly, it sheds light on the effects of planning policies on the lives of recent migrants and informal workers, on potential efforts to support workers who are detached from formal structures, and on fostering social cohesion at the local level.

\footnotetext{
${ }^{1}$ Gremio leader and Santa Cruz city council member Griselda Muñóz invited participants in the two group interviews.
} 


\section{Connections Between the Informal Economy and Urban Public Space}

The extensive literature on public space often takes the perspective of urban design, or social geography, and tends to focus on the architectural, civic, or social qualities of public space. Scholars have mostly concentrated on public space in the developed world, and debates on public space usually refer to northern examples, such as formally planned squares and plazas. Far less attention has been given to public space in the low-income countries, and the role of public space in urban economies and livelihoods, particularly in the global south, is only beginning to be examined (Brown, Kudva). Research on the informal economy, in turn, has emphasized economic factors and structural transformations, while spatial attributes have been mostly overlooked. As a result, our understanding of the relationships between informal labor, policy responses to informal labor markets, and the spaces in which urban residents live and work remains limited (Kudva).

The term "informal economy" is loosely used to refer to a broad range of activity that dominates the economy in many developing cities. It is often used to mean economic activities that are not enumerated or regulated by the state in a legal and social environment in which similar activities are regulated (Castells and Portes 12). Informal activities are relationships that are outside the criminal economy, but fall in a continuum between legal and illegal activities. The products may be legal, but the process through which they are prepared may not be fully legal, for instance when businesses do not pay taxes or are not registered (ibid). The term "informal sector" has been found inadequate as it is not a "sector" in the sense of a specific industry group, and so "informal economy" is used to encompass the diverse group of workers operating informally or under varying conditions of informality (Benería and Floro).

Keith Hart first coined the term informal sector to describe the activity of petty entrepreneurs in Ghana working outside the formal labor market who were largely self-employed. Hart's key thesis was that workers, previously described as marginal, were entrepreneurs in their own right (Cross). In 1972, the International Labor Organization's (ILO) employment mission to Kenya proposed that the informal sector was not marginal but could be profitable and efficient. From this study, the ILO 


\section{REVISTA DE ESTUDIOS BOLIVIANOS}

developed a widely used characterization of the informal sector that included ease of entry, small-scale enterprises, family ownership, use of labor-intensive technology, and reliance on local resources, with a distinction between home-based work and street work (ILO, Castells and Portes, Brown). Since the 1970s, many studies have examined the importance of the informal economy in urban economies in the South and North (Portes et al., de Soto, Benería and Roldán, among others).

In an assessment of previous research, Rakowski proposed two principal approaches in conceptualizing the informal economy. The structuralist approach has argued that the informal sector is an integral part of capitalism because it functions to suppress costs of labor. For example, analyses of subcontracting processes in industries such as apparel and electronics showed that the formal and informal sectors were often highly interconnected. Instead of absorbing informal sector activities - as predicted in earlier studies (e.g. ILO) - the formal sector relied on the informal as a way to increase competitiveness and profits (Benería and Roldán, Castells and Portes). Marxist and dependency theorists, who linked informal employment to uneven capitalist development, have influenced the structuralist perspective (Kudva).

The second approach, known as the legalist approach, is associated with Peruvian economist de Soto. Rather than stemming from the logic of capitalism, de Soto argued that informality is a response to inappropriate government regulation. He stressed that informal operators find it impossible to comply with unreasonable bureaucracy, and that the sector would thrive with less regulation, strengthening of private property rights, and diminished state intervention. More recently, the promotion of small-scale enterprises and informal economic activities has been advocated by development agencies as a strategy for generating economic growth in developing countries and income for the poor, often targeting women (Arbona, Benería, Gill, and Roy).

In practice, the informal economy is characterized by selfemployment but also precarious wage employment, increasing casualization of labor, and activities and processes that may not be fully legal or regulated (Benería). Mapping the informal economy-either the numbers of people involved or their economic output-is difficult and imprecise. Informal sector workers often pursue activities that do not fit researchers' categories, and much economic activity goes unrecorded. Despite the difficulties in measurement, the numbers of people working 


\section{REVISTA DE ESTUDIOS BOLIVIANOS}

informally are widely agreed to be vast and growing. In Latin America, where labor markets have been deeply transformed since the 1980s, most observers agree on "the diminishing centrality of formal employment and the growing reliance on informal work by a large proportion of the population" (Benería 111, Pérez Sainz).

Analysis of the informal economy has distinguished between two types of informalized activities: those linked directly or indirectly to industrial and service work in more formal settings, and those representing survival activities organized at the household and community level (Benería). The former are connected to profit-oriented operations, include a range of self-employment and wage work, and involve micro-enterprises and subcontracting arrangements in both high and low-income countries. Survival activities, on the other hand, represent more precarious forms of self-employment with weak or no links to formal production processes and have limited possibilities for capital accumulation (ibid). These informal activities are the most visible in the urban landscapes of developing cities and are the focus of this paper.

While it is often assumed that small-scale and informal entrepreneurs are self-employed, researchers have pointed to instances in which they are employed by others. For example, Bromley (128-129) identified three types of street vendors in Cali, Colombia. These included outworkers employed by others on a piecework basis; dependent workers (that is, those who are dependent on others for renting stalls, renting equipment, or accessing credit), and the independent, truly selfemployed. He suggested that these relationships form a continuum of wage-work to self-employment, and found that self-employment is less common than might be expected. In addition, unpaid family labor and part-time employment also characterize employment relationships in informal commerce (Brown).

Less studied are the ways in which urban space and territory intersect with work and laboring practices in the informal economy. Kudva noted that research on the informal economy and on the effects of spatial planning have tended to remain separate. She advocated "explicitly" bringing urban space into the debates on informality, including analyzing how spatial attributes serve to enable and constrain the poor and informal workers (Kudva 167). My paper will explore this gap in the literature by focusing on the spatial and political implications 
of expanding informal commerce and in-migration in the local context of Santa Cruz, Bolivia.

\section{Social Exclusion and Contested Urban Space in Santa Cruz}

Since the 1950s, the city of Santa Cruz has received flows of migrant labor, contributing to broader urban growth. During the 1960s and 1970s, international funding focused economic development on largescale agribusiness and highway projects in the Bolivian Oriente, attracting migration to the region (Gill, Eckstein). Migration and urbanization continued in the 1980s, following the shift to neoliberal policies in Bolivia.

At the national level, the neoliberal reforms of the 1980s reduced the public sector, deregulated work arrangements, and decreased the state's role in providing social protections (Benería and Floro, among others). Despite broad reaching macroeconomic restructuring, these reforms have not altered the national economy's basic inability to create adequate formal employment to absorb potential migrants either in source or destination areas (see Kohl). These factors, as well as the effects of globalization and trade liberalization, have contributed to a rise in urban economic informality, affecting Santa Cruz as well as other major Bolivian cities (PNUD).

Informal work in Santa Cruz encompasses a diversity of economic activities spanning small-scale production, home-based industrial work, construction, and services such as car washing, shoe shining, watch mending, phone or internet access, public transport, and a wide array of commerce in food and produce, cosmetics and clothing, and herbs and medicines. Informality is perhaps most visibly (and controversially) reflected in the expansion of open-air markets and street vending that has spread onto adjacent sidewalks, in some cases engulfing any nearby available space. Some observers have referred to the "mercadización" [marketization] of the city, and have used terms like invasión [invasion] and avasallamiento [usurpation] of public space in the local media (Andia 23). Through the use of such terms, informal vendors - many of whom are highland migrants-are portrayed as a threat both to urban public 


\section{REVISTA DE ESTUDIOS BOLIVIANOS}

order and to local and regional traditions. On the website of Nación Camba, a right-wing civic-regionalist group, one writer referred to

These collas who do not respect our customs, who think they can do whatever they want here... who convert our city into a market crushing onto the sidewalks, who close the streets without our consent to celebrate festivals that are not ours, who invade our lands. Santa Cruz is neither a trash bin nor a handkerchief for wiping tears for anyone, nor is it to be sacrificed (García Paz) ${ }^{2}$.

[Estos collas que no conocen ni respetan nuestras costumbres, que creen que aquí pueden hacer lo que les da la gana..., convierten nuestra ciudad en un mercado aplastándose en las aceras, cierran las calles sin nuestro consentimiento para celebrar festividades que no son nuestras, invaden nuestras tierras. Santa Cruz no es un basurero ni un pañal de lágrimas de nadie, y no es para sacrificarlo].

This view shows that hostility toward Andean migrants by some longer-term residents of Santa Cruz is based not only on cultural or economic factors, but also has spatial dimensions. In particular, the streets, sidewalks, and open spaces surrounding large urban markets have become sites where "traditional Santa Cruz" and "newer migrants" meet and collide. Many scholars have emphasized that responses to the challenges of competition in a global economy have reshaped the social and spatial geography of cities (Marcuse, Soja, and Sassen). This process is the result of a growing social divide, increases in flexible, precarious and informal forms of work, and long-term unemployment, both in the global North and South. Urban specialists have connected these symptoms with heightened fragmentation of urban social life and increasing levels of polarization and social exclusion (Castells, Madanipour).

The concept of social exclusion needs clarification due to the variety of contexts in which it has been used. For some, the question of poverty

\footnotetext{
${ }^{2}$ All translations of texts originally written in Spanish are mine.
} 


\section{REVISTA DE ESTUDIOS BOLIVIANOS}

remains paramount, while for others social exclusion makes sense in a broader perspective of citizenship and integration into the social context. In this sense, social exclusion is not necessarily equated with poverty or economic exclusion, although it often causes wider suffering and deprivation (see Roberts). Writing on European cities, Madanipour perceived social exclusion as a multidimensional process, which can take place in economic, political, and cultural arenas. He emphasized that such forms of exclusion often have spatial manifestations, such as in deprived inner city or peripheral areas. In the past, the spatiality of social exclusion has led to attempts to dismantle pockets of deprivation, without attacking the factors that contribute to deprivation or the forces bringing them together in particular enclaves. ${ }^{3}$

Drawing connections between the production of urban space, everyday practices, and economic activities requires a dynamic understanding of space. This entails concentrating on the processes that produce the built environment, as well as how urban space is organized and how spatial practices are controlled and regulated (Olpadwala, Massey). In many cases, a combination of formal rules and regulations, informal signs and cues, and fears and desires regarding openness or restriction influence our spatial behavior and make us aware of limitations or barriers to access to particular places (Madanipour). In this sense, space is more than a neutral background; rather, it plays a central role in the interaction, integration and segregation of urban society. Through analysis of spatial barriers at various scales and by promoting increased accessibility, planners can contribute to expanding social integration and cohesion at the local level.

\footnotetext{
${ }^{3}$ See Peter Marris's classic work on the problems underlying policies of slum clearance, and on the "futility of manipulating change by the logic of physical design" (1974: 49).
} 


\section{Santa Cruz: Urban and Regional Growth and Migrant Attraction}

The city and department of Santa Cruz began a process of rapid economic growth in the mid 1950s, when a state sponsored project paved the road to the highland cities of Cochabamba and La Paz, effectively linking it to the rest of the country (Prado et al.). The city recorded 43,000 inhabitants in 1950, and by 1960 it had 70,000, spread across 5,700 hectares. In the 1970s, the national government strengthened linkages to Santa Cruz through transport and communications infrastructure, including constructing railroads to Puerto Suárez and Yacuiba on the borders of Brazil and Argentina, then the continent's foremost economies. These events occurred in the context of national policies of import substitution in lowland commodities of sugar, rice and timber, as well as expansion of the agricultural frontier, following a developmental approach prevailing in Latin America during this period. The city subsequently diversified its economy along the lines of agribusiness and petroleum extraction, as well as commerce and services. It received waves of migrants from rural parts of the department and from poorer Andean regions, contributing to a current population of over one million, extending over 25,000 hectares (GMSC 2004a).

Santa Cruz consolidated its position as a "motor" of the national economy following state led neoliberal reforms of the mid 1980s. Bolivia's participation in regional trade pacts, Comunidad Andina de Naciones (CAN) and Mercado Común del Sur (MERCOSUR), has favored export sectors based in Santa Cruz, particularly soy and natural gas (Prado et al.). Comprising 34\% of Bolivia's national territory and $25 \%$ of its population, the department of Santa Cruz contributed $30 \%$ of the national GDP in 2001 (GMSC 2004a). The department's share of national exports exceeded $50 \%$ in 2002 , bolstered by rising natural gas sales to Brazil since the 1990s. Its share of foreign direct investment was $36.8 \%$ in 2002, second to Tarija's 39.4\%, and far exceeding La Paz's $10.7 \%$ (CAINCO). According to the regional Chamber of Commerce, Santa Cruz is the largest contributor to the national treasury through taxes and petroleum royalties, producing $40.1 \%$ of Bolivia's tax revenues in 2002 
(ibid). The department's $\mathrm{GDP}^{4}$ per capita and its human development index have exceeded national averages since the 1990s (PNUD).

Santa Cruz department received the highest level of net migration nationally, 428,000 in 2001 , up from 74,000 in 1976 . Roughly $25 \%$ of its two million inhabitants were born outside the department by 2001, with the majority originating in the Andean departments of Cochabamba, Chuquisaca, and Potosí (INE). Highland migrants have formed enclaves in some rural parts of the department, such as Yapacaní and San Julián, and in peripheral areas of the city of Santa Cruz. The state promoted migration to the Santa Cruz region during the 1950s and 1960s through official settlement programs to supply labor and reinforce agro-industrial development programs (Stearman, Urioste and Kay). The impetus of regional economic growth in Santa Cruz, combined with "push" factors related to economic crisis and structural adjustment in the 1980s, along with severe droughts in the highland plateau during this period, have intensified migration flows in the past two decades (PNUD).

\section{Santa Cruz's Changing Spatial and Economic Structures}

The city's physical structure has developed outward from the colonial center, or casco viejo, which is surrounded by a series of ring roads, or anillos. The city abruptly changed from a sleepy "Macondo" to having its first inkling of the rapid growth in the 1950s. At the time, the Italian-Brazilian firm Techint won a bid to design the first comprehensive city plan in 1957. The Plan Techint, drawing on early $20^{\text {th }}$ century European modernist design principles and a 1930s plan of São Paulo, Brazil, envisioned a series of four radio-centric rings, which would enclose self-contained residential units with ample green space. By 1978, the city's population had surpassed Techint's prediction for the year 2000,

\footnotetext{
${ }^{4}$ Gross Domestic Product is an indicator to mesure the health of a country's economy.
} 


\section{REVISTA DE ESTUDIOS BOLIVIANOS}

and new settlements had overtaken the outer limit of the fourth ring (Limpias). ${ }^{5}$ Although the experience of modernist planning of the $1960 \mathrm{~s}$ and 1970s left an imprint on the city's structure, and continues to influence the pursuit of rational urban development, it failed to adequately meet the needs of the vast influx of migrants arriving in the city. Many of the communities that developed outside of the fourth ring meet the UN Habitat definition of informal settlements, characterized by a lack of secure tenure, overcrowding, and insufficient access to basic services such as improved water and sanitation systems (UN-Habitat 19).

The 1995 Plan Regulador [comprehensive plan] divided the city into 12 districts, and neighborhood units within each district or unidades vecinales (UVs). In 2004, the municipality added 4 districts for future growth; these are designated as rural and are largely unpopulated. The location of the 12 urban districts (1-12) and the four rural ones (13-16) are shown in Figure 1.

Traditional families are associated with the central casco viejo and its stately Plaza 24 de Septiembre, but they have begun to disperse to newer affluent residential areas, such as Equipetrol and Las Palmas to the north. Stearman (42-45) observed that the colonial center has been "protected" from outsiders, as Andean (and poorer lowland) migrants settled in areas beyond the outer rings. Continuing waves of rural migrants have claimed urban space in the outer rings, progressively further from the center. The bulk of these migrants are young (between age 18 and 35), seeking work and educational opportunities and an escape from extreme poverty faced in communities of origin (PNUD, INE). Marginal "satellite" cities on the southern and southeastern edges of the city, such as Plan Tres Mil (District 8) and Palmasola (District 9), are currently marked as poor and dangerous (Postero).

\footnotetext{
${ }^{5}$ In this respect, Santa Cruz shows similarities with other Bolivian cities. See Goldstein's (2004) ethnography of Cochabamba, in which modernist planning approaches of the 1940s and 1950s proved incompatible with massive urban migration in the 1970 s and 1980 s.
} 


\section{REVISTA DE ESTUDIOS BOLIVIANOS}

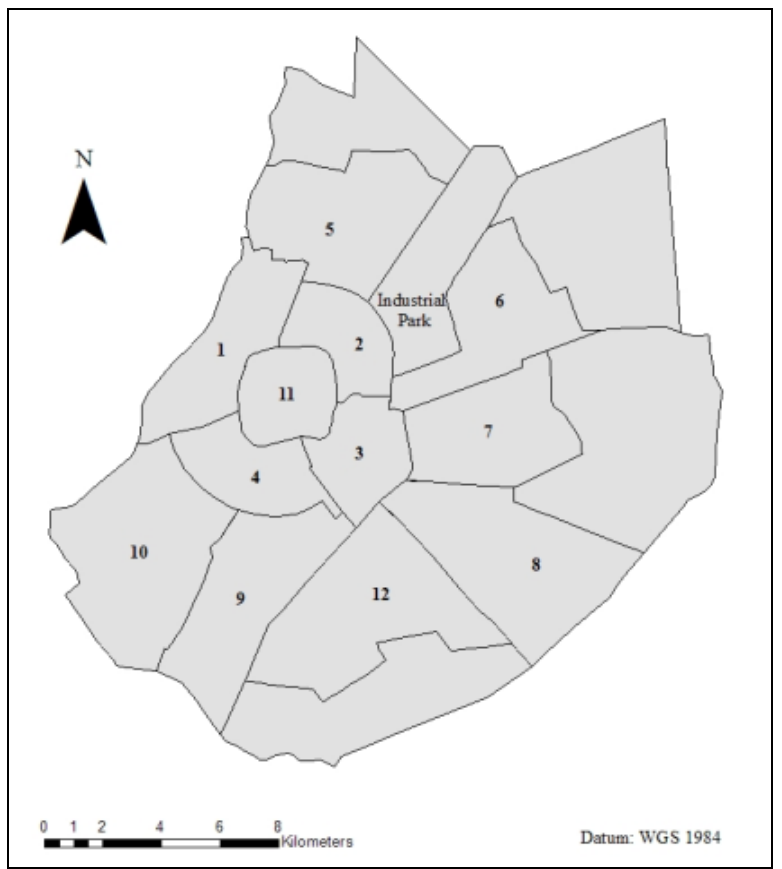

Figure 1: Map of the City of Santa Cruz Showing Urban Districts

The pace of demographic growth has exceeded the capacity of urban planners, local and regional authorities, and members of civil society to respond adequately in meeting basic needs. The result has been increasing segregation, primarily by income, in the absence of planning, and inadequate provision of basic services and infrastructure such as sewage, drainage systems, paved roads, health and educational services in the outer urban areas. Architect Victor Hugo Limpias suggested that local authorities have not intentionally excluded peripheral areas, but instead have been overwhelmed by the pace of growth. ${ }^{6}$

\footnotetext{
${ }^{6}$ Víctor Hugo Limpias, architect and Chair of the Department of Architecture, Universidad Privada de Santa Cruz (UPSA). Personal interview. Feb. 92007.
} 


\section{REVISTA DE ESTUDIOS BOLIVIANOS}

In the past decade, the construction of several national highways has opened up new axes for residential settlement and economic activity on the edges of the city of Santa Cruz. These areas are expanding into the secondary cities of Warnes, La Guardia, and Cotoca, in some cases blurring city boundaries (PNUD). In addition, heightened demand for security has led to the growth of gated communities and high-rise condominiums, which are set apart and far from the city center. ${ }^{7}$ Those designed for elites have recreational spaces such as swimming pools, sports grounds, and even golf courses and horseback riding. New theme parks, such as Aqualand and Playland, attract affluent residents and tourists and are located on the edge of the urbanized area, outside of the municipal jurisdiction (Prado et al.). These trends of urban expansion have resulted in a process some describe as "metropolización" (ibid; GMSC 2004a), leading to increased social and economic polarization, as well as to demands for new and more decentralized forms of urban government (Andia et al.).

The city's economic structure has shifted toward the tertiary sector in the past 20 years. By 2001, the tertiary sector comprised $49.5 \%$ of its GDP and employed $74 \%$ of its working population (GMSC 2004a). In particular, commerce, tourism, and financial activities have been growing faster than other sectors. Many of the multinational firms operating in Bolivia are locating their headquarters in Santa Cruz, in some cases relocating their offices from La Paz. The offices of petroleum firms such as Petrobras, Repsol, and British Gas tend to locate near the fourth ring along axial roads such as Doble Vía La Guardia, Equipetrol Norte, and Avenida Banzer. Financial and producer services, such as banking, insurance, and advertising, are concentrated in the central casco viejo, within the first ring. Here, newly erected shopping centers and sleek apartment complexes are edging out decrepit colonial era buildings, and there has been an effort to renovate and refurbish older buildings.

\footnotetext{
${ }^{7}$ This trend follows Latin American mega cities such as São Paulo and Mexico City (see Caldeira, City of Walls: Crime, Segregation and Citizenship in São Paulo; and Cabrales Barajas, "Gated Communities Are Not the Solution to Urban Insecurity").
} 


\section{Rising Labor Informality}

Official data for the city of Santa Cruz suggest that informal forms of employment, including micro-enterprises, domestic service, and selfemployment, account for roughly two thirds of the city's employed population (GMSC 2004b). Self-employment is more concentrated in the peripheral and poorer areas of the city than in more affluent central areas, but it is prevalent throughout the city (INE). However, a higher percentage of recent migrants have been shown to work in formal occupations as compared to the population as a whole of the department of Santa Cruz (PNUD). This belies the common stereotype in Santa Cruz that recent migrants are confined to the most degraded and informalized parts of the economy.

Writing on the Santa Cruz urban economy in the 1980s, Rojas Rosales emphasized that in commerce and small-scale manufacturing, informal employment arrangements predominate over formal ones. The author noted that informal work involves productive units that are not highly capitalized and use labor without contracts and often through unpaid family arrangements. Furthermore, key segments of the urban economy-ranging from construction and transport services, as well as productive activities in food and beverages, wood products, garments, leather and metals-have increasingly informalized. Such activities often compete openly with formal counterparts in the same industry. Based on these observations and echoing theoretical analysis of the informal economy, Rojas Rosales concluded that informal workers are not merely "leftover" parts of the urban labor market of Santa Cruz, but rather provide essential services for the city and in many ways subsidize portions of the formal, capitalist sector (Castells and Portes, Benería).

In the period since Rojas Rosales made these observations, processes of labor market informalization and urban expansion have intensified in Santa Cruz. Drawing on evidence from Delhi and Ahmedabad in India, Kudva has suggested that urban growth is being supported by increased informalization of labor markets in these cities. A similar relationship is at work in Santa Cruz. Moreover, the enlarging informal economy is altering the urban landscape. For example, the shifting of production from centralized places of employment to smaller, decentralized sites, including micro enterprises and workshops in 
residential areas, as well as home-based work, is producing a form of urban growth that reflects rising social segregation (Kudva). This process also involves the conversion of public spaces, such as parks, plazas, and streets, into market places and sites of informal commerce (Benería and Schaller).

\section{Informal Commerce in Santa Cruz and Gremio}

\section{Associations}

Although they have long faced social and political marginalization, informal vendors have gained political influence in the city of Santa Cruz during the past two decades. This political influence reflects their growing numbers, strong forms of organization, and increasing opportunities for capital accumulation in the urban economy (Rojas Rosales). Urban Andean merchants have organized self-governing associations, or gremios [guilds], to defend their interests to the municipality. Beginning in the 1990s, the gremios have gained a political niche in the municipal government through representation on the City Council. Although comprised of both migrants and non-migrants, the gremios and the large urban markets they occupy are often viewed in the popular imagination as "colla" (Andean) spaces in the city (Gustafson).

Gremio associations emerged as part of the trade union movement in highland Bolivian cities. ${ }^{8}$ While scholarly research on gremios is limited, particularly focusing on Santa Cruz and the lowlands, Rojas Rosales (108) noted they appeared in Santa Cruz shortly after the 1952 revolution, most likely brought directly by highland migrants. As a representative structure organized into regional federations and national confederations, the gremios have become a bastion in the fight of informal vendors against municipal control of public space. They also represent vendors in negotiations with local residents and mediate and

${ }^{8}$ On the role of gremios in local associational life and in recent popular mobilizations in highland cities, see Lazar, "El Alto, Ciudad Rebelde: Organizational Bases for Revolt" and Albro, "The Culture of Democracy and Bolivia's Indigenous Movements." 


\section{REVISTA DE ESTUDIOS BOLIVIANOS}

resolve conflicts between individual affiliates (Andia, Lazar). Several observers have emphasized the strong organizational capacity of the gremios (Andia, Rojas Rosales, and Salek 2007a). In Santa Cruz's largest market, La Ramada, 60 gremios are present. A recent study found that $94 \%$ of the vendors at La Ramada are members of a gremio.

Furthermore, these $94 \%$ of respondents all stated that their organizations have elected leaders and functioning statutes (Andia) ${ }^{9}$.

Andia observed that labor migration flows, particularly those from the Andean highlands, have sparked a regionalist and at times racist stance by elites and civic leaders in the city. He linked this stance with heightened political and social exclusion of highland migrants, especially those involved in small-scale commerce, in many cases self-employed. These workers become visible targets for anti-migrant sentiment, as shown in the quotation cited earlier from the "Nación Camba." Largely excluded from social expression and political participation, these migrants have experienced a "postponed citizenship" and lived as "second-class members of society" (Andia 25).

These dynamics began to change with the mayoral election of Percy Fernández in 1991. Percy Fernández sought to expand access to the political process to all of the city's residents and to treat newcomers in the same manner as traditional Cruceños. Immigrant merchants began to have an imprint on local politics. Representing swelling ranks, the gremios strengthened and solidified their organizations to become recognized local political actors. However, Percy Fernández's administration did not make concrete advances in relations with the gremios or with issues related to public markets. In Andia's view, the mayor's office tended to view local citizenship as the sum of individuals within the city and did not forge connections with collective organizations such as the gremios. This could explain why "the same people who benefited from gains in health care and paving roads were ignored when they brought up collective problems related to public markets or conflicts over urban land" (Andia 26).

In 1995, a change in the city's politics took place. Johnny Fernández unexpectedly defeated Percy Fernández in the municipal elections (the two are not related). The son of a Cochabamba beer magnate and

\footnotetext{
${ }^{9}$ Andia conducted the survey in September 2001 among vendors at La Ramada, with a sample of 300 vendors, stratified by sector.
} 


\section{REVISTA DE ESTUDIOS BOLIVIANOS}

populist political figure, Johnny Fernández campaigned on his strong connections with popular organizations, many of which had long been excluded from traditional local political parties. Among these was the federation that comprised most of the gremios in the city at that time, led by Jesús Cahuana, himself a migrant from the highland city of Oruro. With the appointment of Cahuana to the City Council in 1996, the gremios began to play a direct role in local representative politics.

\section{The Problematic of Large Public Markets}

According to a census taken in 2000 under the auspices of the City Council, there are 22 municipal markets with 20,000 vendors, 30 private markets, as well as numerous informal markets, known as asentamientos in Santa Cruz. The census estimated a total of 35,000 vendors, or gremialistas, in the city's markets (Andia). Updating this information in 2007, the Oficialía Mayor de Planificación [Municipal Planning Agency] recorded 34 municipal, 36 private and 18 asentamiento markets, with a total of 88 markets (Salek 2007a).

Municipal markets are located on public property, owned by the municipal government, and they serve as important points of reference in the city. These markets figure prominently on city maps and most of the city's dozens of minibus lines organize their routes to stop at several of them. The municipal markets include a range of economic activity such as formal merchants, self-employed merchants and vendors, and waged and unpaid family work arrangements, as well as both fixed and ambulatory vendors who circulate around the edges of the markets. Private markets are owned by private firms, mostly based in Santa Cruz, and are similar to North American supermarkets; thus, they are not informal. The informal asentamientos have little or no municipal control and are often formed spontaneously and unnamed. The asentamientos include self-employment and some waged and unpaid family work that is unregistered and informal. Figure 2 shows the proportion of the three types of markets in the city. 


\section{REVISTA DE ESTUDIOS BOLIVIANOS}

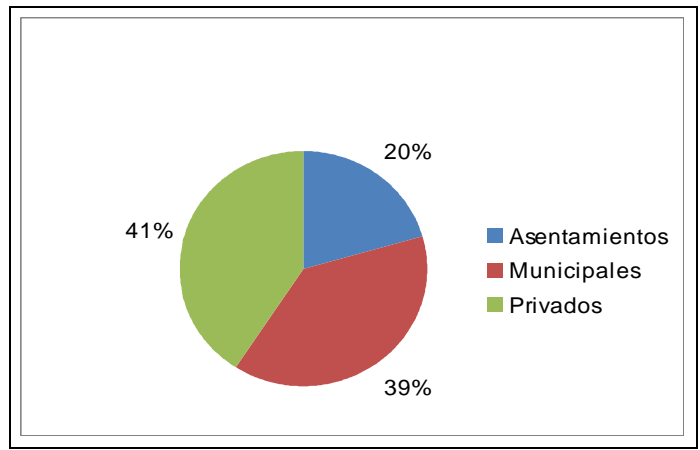

Figure 2: Proportion of Markets in Santa Cruz, 2007

Source: Salek 2007a

Reflecting the increased income inequality and socio-economic segregation in Santa Cruz, the three types of markets are not distributed evenly across the city. Figure 3 shows the total number of municipal, private and asentamiento markets in each of the 12 urban districts. Figure 4 maps the locations of these markets in the city, and also shows a proposed wholesale market, or Mercado Mayorista.

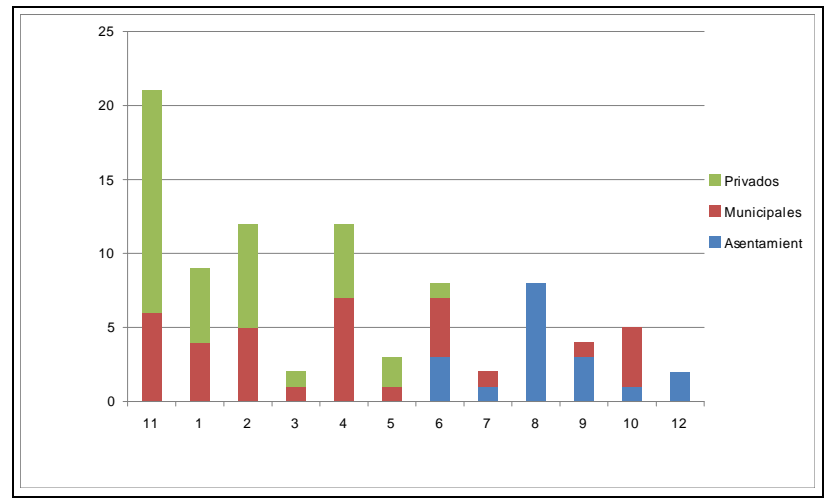

Figure 3: Number of Markets by Urban District, 2007

Source: Salek 2007a 


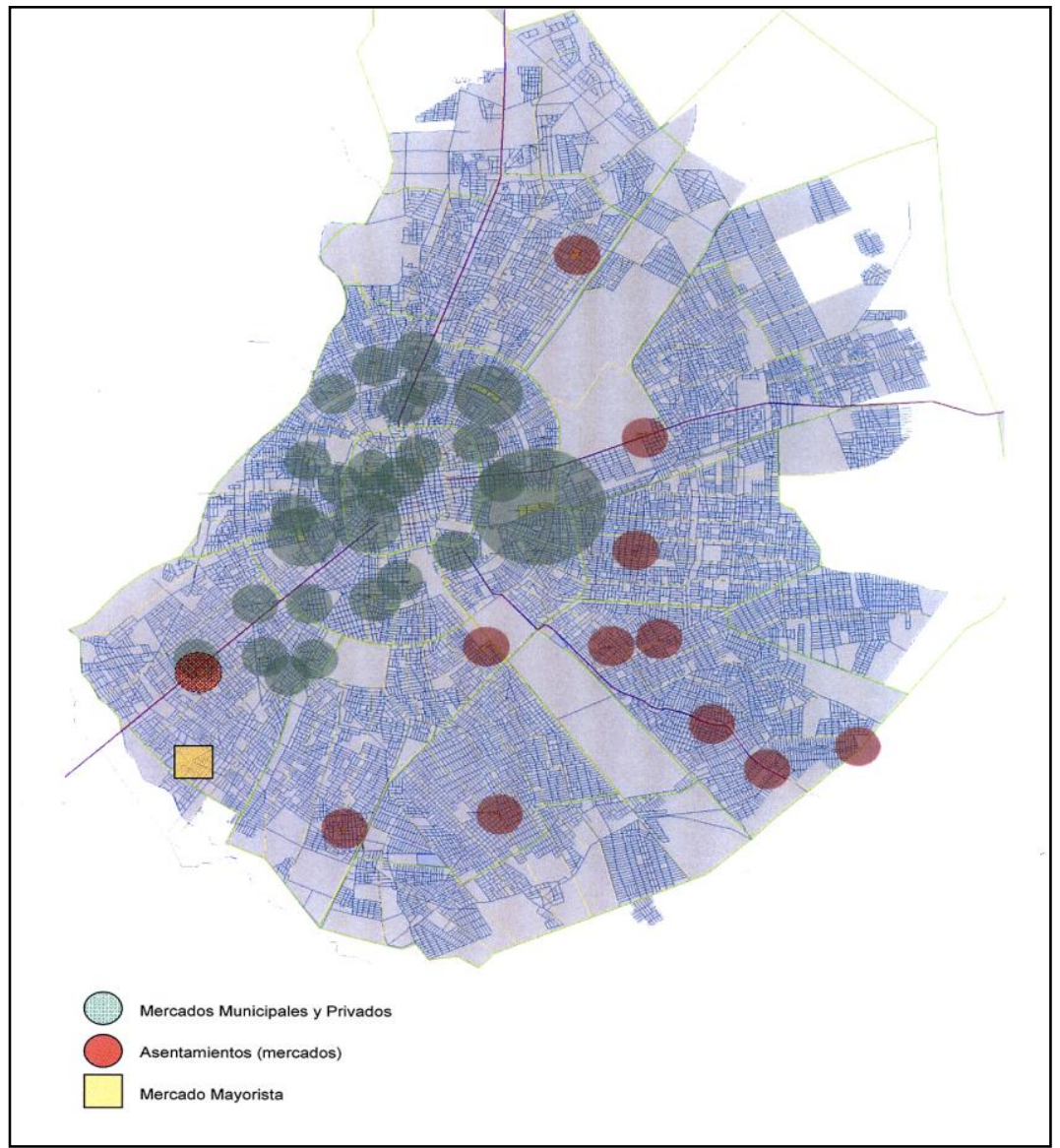

Figure 4: Map of Market Locations in Santa Cruz Source: Salek 2007a

As shown above, the vast majority of municipal and private markets are located in the centralized and more prosperous Districts 1-4 and 11, with a smaller number in intermediate Districts 5 and 6 . District 11, in the city center, has the largest number of both municipal and private markets. In stark contrast, the informal asentamientos are concentrated 


\section{REVISTA DE ESTUDIOS BOLIVIANOS}

in outer Districts 7-10 and 12, indicating a lack of market infrastructure in the urban periphery. The poorest districts, 8 and 12, have only asentamientos. District 12 , the most recently established, has only two asentamientos. District 5, which is far from the center but houses many newer affluent and "gated" communities, lacks municipal markets but has several private ones. Meanwhile, the largest municipal markets, La Ramada, Los Pozos, Abasto, and Mutualista, are all located in central zones within the fourth ring.

The large municipal markets experience varied and complex problems related to overcrowding, lack of cleanliness, and hygiene, conflicts between established vendors and the newly arrived, competing pressures for land, and encroachment of vendors onto areas officially designated as public space. Several of these markets were formed in the early 1970 s when city planners began implementing the city's first comprehensive plan, which envisioned self-contained neighborhood units and a decentralized supply system (Palmer). This decentralized supply system did not materialize, and the central markets expanded along with rapid urban growth in the 1980s and 1990s. Since the municipal government did not intervene when the central markets began to expand, the problems have grown more burdensome to resolve. Absent effective intervention, expanding informal commerce in public spaces is generating social conflict. For instance, pedestrians often find sidewalks filled with vendors' wares impassible. Disputes erupt between formal shopkeepers and informal merchants selling the same items from the front sidewalk. Another set of problems relates to environmental damage, such as food vendors cooking on the street and disposing of cooking oil onto the sidewalk or grass. ${ }^{10}$ Public transport, also largely informal and not regulated by the municipal government, converges around the largest central market areas, exacerbating congestion and air and noise pollution (Salek 2007b).

Andia cited insufficient municipal funds to invest in upgrading the municipal markets, as well as a lack of administrative policy towards them. As a city council member, Cahuana sought to rectify this situation when he became president of the Comisión de Industria y Comercio, a commission of the City Council. In 1998, the commission developed the

\footnotetext{
${ }^{10}$ Nadine Salek, Municipal Planning Agency, City of Santa Cruz. Personal interview. July 242007.
} 


\section{REVISTA DE ESTUDIOS BOLIVIANOS}

Macropolítica Municipal de Mercados, which proposed the construction of district-level markets and wholesale produce markets at three of the city's main entry points. ${ }^{11}$ Several years earlier, the municipal government had passed an ordinance (Ordenanza Municipal 21/90) allowing usufruct ownership of market premises, in which vendors would exercise ownership for 30 years, at which point ownership would revert to the municipality (GMSC 1990). According to Cahuana, the usufruct system enabled some US\$ 50 million of investment in market infrastructure while it was in effect, improving working conditions for vendors.

But critics have faulted the system with weakening municipal control over markets and adjacent public spaces (Salek 2007a, 15) and noted that it allowed the sale of usufruct rights to other vendors, creating a "disorganized and chaotic situation."12 Furthermore, Cahuana has been rebuked for acting "in the interest of the gremios-and even worse, a specific sector of gremios-rather than for the general interest of the city" (Andia 32).

In Andia's analysis, two factors are at work in the municipal government's approach toward the public markets, namely a perception and an ideological factor. First, it recognizes that it has a physical and social problem on its hands, in which expanding markets occupy space, annex neighboring areas, worsen congestion, and thwart efforts to create rational, orderly urban growth. There is also an ideological issue at play, relating to the elite civic powers in the city and their opposition to "unhygienic" and "informal" uses of public space, as well as to the rising political muscle of the gremios and other associations of informal workers.

The ideological issue is rarely made explicit. However, one view maintains that under Mayor Johnny Fernández, leaders of the growing urban informal economy, including the gremios and the informal transport sector, created alliances with political parties "to support the interests of markets, street commerce, and illegal occupation of public land" (Prado et al. 164). These alliances have drawn criticism as a form of

\footnotetext{
${ }^{11}$ Jesús Cahuana, President, Federación Unica Departamental de Trabajadores Gremiales, Comerciantes Minoristas, Artesanos y Vivanderos de Santa Cruz. Personal interview. Dec. 102007.

${ }^{12}$ Lorgio Ardaya, Office of Consumer Protection. Personal interview. July 242007.
} 
"patronage politics" in which "electoral votes are exchanged for favors in the use of public space that benefit the interested parties, while creating conflicts for the city at large" (164). The gremios continue to exert pressure on the local government and can mobilize their members in large demonstrations, but they are often stigmatized as uncooperative, conflictive, and causing disorder (Salek 2007b).

A competing view holds that the municipal government has not succeeded in making concrete improvements in the city's markets. Cahuana noted that the municipal budget relies on fines levied on street vendors and that the current administration deliberately keeps the rules murky to extract higher rents. Moreover, the new municipal plan to reorganize market networks does not recognize the authority of gremio leaders and does not seek their input. "When we organize marches and mobilizations, we do so to remind the municipality of its obligation to improve market infrastructure," explained Cahuana. In the context of public sector retrenchment and the diminished role of the state in social provisions, commerce offers a source of livelihood for many urban residents.

\section{Municipal Plan to Reorganize Markets and Market Networks}

The Santa Cruz city government, again under Mayor Percy Fernández since 2002, has retaken initiative on limiting the growth of urban markets and informal economic activities in public spaces. In 2007, with support from the Japanese International Cooperation Agency (JICA), the Oficialía Mayor de Planificación prepared a diagnostic report on the proliferation of markets and street vending, and it has begun to implement the Plan Municipal para la Nueva Red de Abastecimiento, Mercados, Ambulantes y Asentamientos Comerciales en el Espacio Público [Municipal Plan for a New Supply Network, Markets, Ambulatory vendors, and Commercial Activities in Public Spaces] (Salek 2007a).

The report lists factors contributing to the growth of informal commerce, citing poverty and lack of employment alternatives, insufficient skills needed to access the formal economy, tax avoidance, 


\section{REVISTA DE ESTUDIOS BOLIVIANOS}

lack of "identification with and commitment to the city," customer preference to buy certain goods informally, and weak institutional control by the local government (Salek 2007a, 4). The report states that informal commerce may be "invasive" and even "illegal," but it recognizes that the vendors pursue livelihoods and dignity, and therefore the municipality should find "mechanisms to resolve the problem through economic, social, and urban policies" (Salek 2007a, 5).

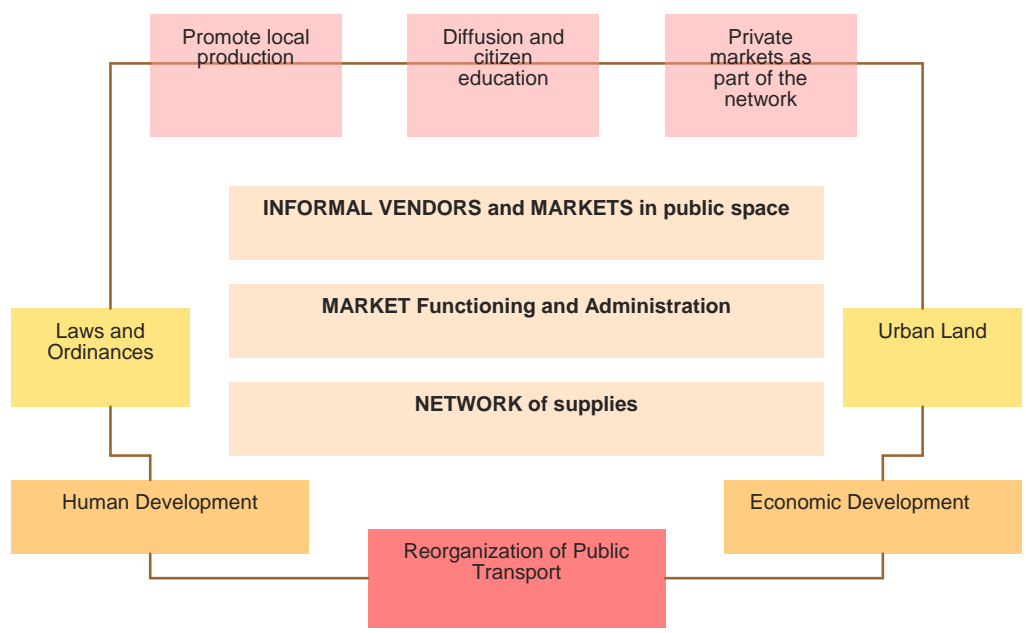

Figure 5: Diagram of the Municipal Plan for the New Market Network Source: Salek 2007a

The Municipal Plan proposes a three-part approach to address these issues. The first part involves decentralizing the largest public markets and creating new district-level markets in the outer districts. Ambulatory vendors concentrating in the largest central markets would be "relocated" to stalls in the new district markets. The second part includes improving the internal functioning and administration of markets, organizing officially sponsored outdoor fairs for specific products, and creating centers for the sale of foods. The third part involves designing a 


\section{REVISTA DE ESTUDIOS BOLIVIANOS}

new food distribution network, and it includes creating a wholesale produce market and providing technical and financial assistance to associations of vendors and gremios in areas such as health and hygiene. Overarching goals include improving the city's supply system, decongesting the principal municipal markets, rotundas, and avenues, enhancing market infrastructure through spatial planning, and developing clear norms and regulations regarding the markets and their surrounding areas (Salek 2007a, 22-25).

In this way, the plan seeks to formalize segments of the retail sector that are informal and to bring these informal activities under the city's regulatory structure. According to Lorgio Ardaya, Director of the Municipal Office of Consumer Protection which oversees enforcement of public space regulations, "the central feature of the new plan is that the new district markets will house those who were dedicated to using public space for commercial activities" (Ardaya).

Much of the Municipal Plan-including the proposed wholesale and district markets-draws on the Macropolítica Municipal de Mercados, developed when Cahuana headed the municipal commission on public markets but not implemented. According to Cahuana, the main difference is that the new plan "does not recognize the gremio leadership." He added that rather than using the system of usufruct ownership rights for vendors, private firms will be encouraged to invest in infrastructure development through a bidding process. ${ }^{13}$ Vendors must accept "whatever price, whatever location, and whatever dimensions" these developers demand for their premises (Cahuana). Furthermore, while the plan advocates an "integral approach" to improving the city's commercial and distribution system though multiple interventions, it had not, at the time of my fieldwork in 2007, specified how the new district markets will be allocated, their specific locations, or how the relocation of ambulatory vendors will be carried out.

${ }^{13}$ This point is confirmed in Salek (2007a). 


\section{Responses to the Municipal Plan and Competing Views of Public Space}

Reactions to the unfolding Municipal Plan reveal different perceptions of urban space and the way these perceptions relate to the challenges posed by the expanding informal economy in Santa Cruz. The following discussion draws on a series of individual interviews and two group interviews conducted during field research in 2007. Many of the vendors interviewed are not inherently opposed to the Municipal Plan and would consider moving to new locations sanctioned by the municipality under certain conditions. They are often critical, however, of the program's non-participatory structure and the manner in which they feel it is being imposed on them. A female member of the Asociación 8 de Enero, a gremio based at the central Los Pozos market with 360 members, stated that

We have unified five federations of gremios. Only the head of the federation attends the meetings [with the municipal government]. The membership base is not informed. They don't consult with us about the project. We don't know very much about it" (Personal interview. August 24 2007).

[Nosotros hemos hecho una unificación de cinco federaciones. Solamente la cabeza de la federación va a las reuniones. La base no sabe. No nos consultan sobre el proyecto. No lo conocemos bien].

Other gremialistas worried that relocating away from the city center, with its high pedestrian flow, would hurt their sales. A female member of the Asociación 8 de Marzo, also based at Los Pozos with 400 members, responded that "We won't be able to sell anything, so what will we live on? They should accommodate us well; if not, we cannot move" [No vamos a vendor nada, ¿de qué vamos a vivir? Ellos tienen que acomodarnos bien, o si no, no podemos ir] (Personal interview. August 24 2007). A male member of the same gremio stated 


\section{REVISTA DE ESTUDIOS BOLIVIANOS}

They are going to build a new municipal market. We don't think we'll stay here forever. Mayor Percy Fernandez has offered us a place [in the new market] and we are waiting for it. But I hope they don't relocate us too far away, in the middle of nowhere. We have capacitated ourselves, and they can't just send us away, just like that. Now, if they give us a place near the third or fourth ring, yes, we'd accept it. But only if there is transport available on the main road. If not, we'll fight until who knows when..." (Personal interview. August 24 2007).

[Se va a construir un mercado municipal. No pensamos quedarnos aquí para siempre. Nos han ofrecido el Señor Alcalde Percy Fernández, nos esperamos. Pero que no nos lleve al quinto infierno, que al bobi nos come. Ya nos hemos capacitado, ya no nos puede llevar por así nomás. Ahora si nos dá acá en el tercer anillo o el cuarto anillo, sí aceptamos. Pero siempre y cuando que haya las movilidades alrededor en una avenida. Si no, tendremos que pelearnos, hasta cuándo...].

Underscoring this view, Cahuana, the gremio federation leader and former council member, noted

Percy Fernández built a market called Miraflores in the zone of Villa Primero de Mayo, for political reasons, in the early 1990s. Right now, it is empty. It cost $\$ 400,000$ in investment. Why? There is no vehicle or foot traffic. It's like new, but it's falling down. People who don't know the basics of commerce, they just do whatever they want (Personal interview. December 10 2007).

[El Percy Fernández construyó un mercado que se llama Miraflores en la Villa Primero de Mayo, por cuestiones políticas, a principios de los 90. En este momento, está vacío. 400 mil dólares de inversión. ¿Para qué? No hay tráfico de vehículos ni peatonal. Está nuevito, pero está 
cayéndose. La gente que no conoce el rubro de comercio, hace lo que le da la gana].

These testimonies reveal an understandable concern with livelihood strategies among informal vendors. If they are forced to relocate far away from the city center, vendors may sell less, and a long commute could cut into meager earnings. There is also a spatial dimension to these livelihood concerns, for instance in the above statement on the acceptability of relocating to the relatively central third or fourth ring, or the infeasibility of a poorly situated new market. Although few urban planners and managers recognize it in local poverty alleviation programs, urban space can be considered an important resource for livelihood, affording crucial access to customers and suppliers.

While prioritizing livelihood strategies, many vendors recognize the need for a system of rules regarding access to urban public space. Asked about what happens when new arrivals, such as recent migrants, want to join a gremio in Los Pozos, another member of 8 de Enero commented: "Now there is no more space. Each association has its members and there are nine associations here. There can no longer be disorder in the streets" [Ya no hay espacio. Cada asociación tiene sus números, sus socios. Nueve asociaciones hay acá. Ya no puede haber el desorden de las calles].

Currently, Griselda Muñóz serves as the Director of the Federación de Gremialistas and is an elected city council member under Mayor Percy Fernandez. ${ }^{14}$ She often has served an intermediating role between the municipality and the gremialistas. According to Muñóz, "The municipality has not constructed a single market in 20 years, it hasn't constructed absolutely any infrastructure. All of the markets exist because of the resources of the merchants" (Personal interview. August 8 2007). [El gobierno municipal no ha construido ni un solo mercado en los últimos 20 años, no ha construido absolutamente ninguna infraestructura. Todos los mercados que existen son con los recursos de los mismos comerciantes]. She adds

\footnotetext{
${ }^{14}$ Griselda Muñóz and Jesús Cahuana represent different federations of gremios and are members of different political parties. Muñóz is a member of the centerright Agrupacion Ciudadana Siglo XXI, while Cahuana belongs to the center-left Union Cívica Solidaridad (UCS).
} 


\section{REVISTA DE ESTUDIOS BOLIVIANOS}

What is missing is a market policy and a policy on the use of public space by the municipality that permits the decongesting of the older markets and the construction of new ones, that the new markets have defined spaces with set schedules for work, and guidelines on what should be sold, what you can sell in the Casco Viejo [city center] and what things you cannot sell. Now they sell anything, there is no order, and this stems precisely from the political problems and from corruption (Personal interview. August 8 2007).

[Falta una política de mercados y de uso de los espacios públicos para el gobierno municipal que le permita los asentamientos antiguos descongestionarlos en las construcciones de nuevos mercados, y que los nuevos asentamientos ya tengan áreas destinadas y definidas con horarios, con tiempos de trabajo, inclusive actividades que puedan hacer, qué cosas se pueden vender en el Casco Viejo y qué cosas no se pueden vender. En este momento se vende de todo, no hay un ordenamiento, $y$ justamente esto se viene a raíz de la cuestión política y la corrupción].

In Muñóz's view, the gremialistas are willing to collaborate with the municipality on the Plan Municipal, but she questions the underlying motives behind it and the lack of channels for participation in its design. She also has some of her own ideas and priorities on how to improve the conditions of market vendors.

The majority of us have educated our children in the streets. If you go to the Ramada market, where my association is... You'll see that we've educated our kids in the streets, and I know from my own experience that this is not an adequate place for them to do their homework and to learn. It would be a good idea if a private company - because the mayor's office will never be able to do this, they can't even supply municipal daycare centers - or an NGO or foundation could construct spaces 


\section{REVISTA DE ESTUDIOS BOLIVIANOS}

near the markets where children could do their homework seated on chairs, at desks, as they should be.

[La mayoría de nosotros hemos educado a nuestros hijos en las calles. Si Ud. va al mercado La Ramada donde está mi sindicato... Hemos educado a los hijos en las calles, y yo veo de mi propia vivencia que no es un lugar adecuado para hacer las tareas y aprender. Sería bueno que alguna empresa privada - porque la alcaldía nunca lo va a hacer porque ni guarderías municipales tiene- alguna ONG o una fundación podría hacer cerca de los mercados lugares donde los niños puedan hacer sus tareas sentados en sillas y mesas como corresponde].

Muñóz proposes that through a local economic development program, market vendors' children could be taught certain skills to create value added products, enabling them to have opportunities outside of informal commerce. In addition, she feels that public authorities should gain familiarity with local informal production processes and linkages between informal and formal production and markets, so that they can support the vendors in more effective and creative ways, rather than considering relocation as the only solution.

\section{Ordenanza Municipal and "Official" Conceptions of Public Space}

The municipal government's views and policies on uses of public space are demonstrated in the Plan Municipal de la Nueva Red and in an ordinance on public space developed in 2004, the Ordenanza Municipal de Espacio Público 050/2004. ${ }^{15}$ The ordinance lays out categories of economic activities permitted in public spaces, rights, norms, and

\footnotetext{
${ }^{15}$ This ordinance was in the process of being re-approved by the City Council in 2007.
} 


\section{REVISTA DE ESTUDIOS BOLIVIANOS}

regulations, and enforcement procedures. Vendors are required to register and to pay operation fees, visibly display authorization, and follow technical specifications on amount of space used, and they can be fined for not complying with guidelines. The Oficina de Protección al Consumidor [Office of Consumer Protection], under the municipality's Oficialía Mayor de Defensa Ciudadana [Office of Citizen Defense], is charged with enforcing the regulations (GMSC 2004a).

Close examination of the municipal ordinance suggests how the local government conceives of public space, and how it views appropriate uses of public space. According to the text of the ordinance, the municipality must "guarantee equality of opportunities in accessing public space and the smooth functioning of activities in such spaces... without causing harm to pedestrians or vehicular traffic flow." It outlines a series of objectives on the uses of public space, including "protecting the environment [...] improving the quality of public space through its rationalization and designation of compatible uses according to established zones [...] recuperating and preserving public spaces so that areas of circulation, green space and public ornamentation complete their functions [...] prioritizing collective interests of citizens above individual interests, and ordering activities in public space under aesthetic and functional conditions approved by the Oficialía Mayor de Planificacion" (GMSC 2004a 4).

The ordinance includes a definition of public space that has a legal and a socio-cultural dimension. From a legal perspective, public space is understood as a "public dominion" meant for "satisfying collective urban needs," which "transcend individual interests of the city's inhabitants and are subject to regulation by public administration." From a socio-cultural perspective, "public space has the role of enabling social interaction, communal expression, and the construction of citizen identity" (GMSC 2004a 5). The ordinance notes, "in this city in particular, with its history of migrant reception, a diversity of people live together who leave their mark on the urban landscape" (GMSC 2004a 6).

Based on these stipulations, it seems clear that the municipality recognizes that public space in the city encompasses multiple uses, including those of diverse cultural and ethnic origins, such as selling a range of products and services. However, it reserves the right to set limitations, such as on infringement of green space, harming traffic flow, or activities considered unhygienic or unsanitary, including certain forms 


\section{REVISTA DE ESTUDIOS BOLIVIANOS}

of food preparation. Municipal planners, drawing on traditions of European modernist city planning that have influenced other Latin American cities, value a "rational" approach to organizing uses according to appropriate zones and an orderly separation of functions (Hardoy, Goldstein). In some public places, such as the central Plaza 24 de Septiembre, informal commerce is completely barred. Concepts of public order and spatial aesthetics have led to a desire to 'tidy' and 'control' public space, while overlooking the realities of mass urban migration and the challenges of urban poverty.

Furthermore, the ordinance states the priority of "collective" interests above those of individuals. Ironically, the municipal government seems to contradict this position in its efforts to limit the popular-collective gremio organizations. Finally, the municipality shows a concern for the patrimonio paisajístico [landscape patrimony], and imagen urbana [urban image], perhaps in order to attract foreign investment, tourism, and enhanced connections to the global economy, as well as to project symbolic qualities such as civic life and "modernity" (Muñóz, Hardoy).

\section{Implications of Competing Views of Public Space}

Regarding the uses of public space in the city, the municipal government emphasizes notions of aesthetics and public order to promote an image of a modernizing and cosmopolitan city. The ordinance on public space and the Municipal Plan advocate for "collective urban needs" while condemning certain economic activities as inappropriate and based on "individual gain" (GMSC 2004a 5, Salek 2007). From the standpoint of vendors and their organizations, however, they are exerting a right to work, which is equally part of the city's "collective interest." Moreover, they are exerting this right in the context of deteriorating labor market conditions and the diminished role of the state in providing social protections (Benería and Floro, Gill). Although street vending in public space offers individual gain, the collective potential for poverty reduction through the use of urban public space for livelihoods can be considered as a wider social benefit. 


\section{REVISTA DE ESTUDIOS BOLIVIANOS}

The strategy being pursued by the municipality is to relocate informal vendors to specific zones in return for granting them official recognition. However, the designated new market areas are likely to be located away from the busy city center, depriving vendors of customers and easy access to suppliers. As with much economic activity, spatial location is crucial for the viability of micro-enterprises operating in urban public space (Brown). In the context of increasing privatization of urban space, such as through private shopping centers and gated communities, public space becomes an important resource for the poor, albeit one whose use is not encouraged by local public policies. The Municipal Plan seeks to restrict economic activities in public space and uses negative terms such as avasallamiento [usurpation] and invasión [invasion] to describe it.

The discourse of avasallamiento is used in other contexts in Santa Cruz to refer to something anomalous, disordered, and unwanted, suggesting that street vendors are not merely considered a nuisance but also a threat to public order and local tradition. Specifically, the term avasallamiento has been used to characterize both urban migrants moving into certain parts of the city (Andia), and rural migrants who have made land claims in areas of Santa Cruz, threatening agribusiness interests (Gustafson, Urioste and Kay). In this sense, the concept of avasallamiento relates to Mary Douglas's notion of dirt as matter out of place, laden with connotations of danger when it is perceived as transgressing boundaries. The fact that urban migrants have organized gremio associations and made claims to the municipality has added to the tension surrounding issues of access and use of public space. The critical question is the extent to which public authorities and urban elites seek to limit and exclude the activities of largely migrant vendors, and the poor more broadly, and how the vendors contest these policies.

According to Cahuana, the Municipal Plan is simply a "political issue," rather than an outright effort to discriminate against highland migrants (Personal interview. Dec. 10 2007). But it seems clear that battles over territorial control of urban space are a key arena in which the issue of migrant integration plays out in Santa Cruz. 


\section{Conclusions}

This paper has highlighted some of the ways in which migration flows and increasing economic informality have a direct bearing on patterns of urbanization and changes in the urban landscape of Santa Cruz, Bolivia. It has also considered the linkages between these processes and municipal policies. While the local economy has shown a rise of informality across economic activities, this study has concentrated on informal commerce as a key area due to its visibility in the public sphere. As Kudva has emphasized in an analysis of urban informality in Delhi and Ahmedabad in India, there is a dialectical relationship at work between social and spatial structures and development. Urban spaces contain and circumscribe social structures, while these spaces are also the product of societies that enable and shape their construction (Kudva 2006). Exploring this dialectical relationship is useful for moving beyond deterministic arguments about the nature of society and space (Soja 2000). It is also useful for analyzing the dynamics of employment and the everyday struggles faced by informal vendors.

The city of Santa Cruz is increasingly linked to the global economy through policies implemented at the regional and national scale in the 1980s and 1990s. These policies include privatization of state firms, trade liberalization, and the growth of export commodities such as cotton, sugar, and increasingly soy and natural gas (Benería and Floro 2006, Prado et al. 2005, PNUD 2004). As a result, Santa Cruz is affected by economic policies that take place beyond the scope of its political control. At the same time, local politics mediate the effects of these global connections. ${ }^{16}$ This opens up political spaces for opposition to dominant policy regimes at the local level.

The Santa Cruz city government has proposed the Plan Municipal de la Nueva Red as a means to improve distribution networks and the functioning of markets, reduce harmful congestion, and resolve protracted conflicts over uses of public space. It seeks to regulate and standardize land use practices and uses of public space, while suppressing certain activities deemed undesirable by authorities.

\footnotetext{
${ }^{16}$ See Fainstein (2006) for examples of local mediation in global cities.
} 


\section{REVISTA DE ESTUDIOS BOLIVIANOS}

However, the result of such a policy approach may be a widening gulf between formal and informal sectors of the local economy. The Plan Municipal seems in part aimed toward pursuing a more cosmopolitan and even "global city" status for Santa Cruz. This is achieved through redistributing market networks and relocating some vendors away from central zones of the city.

Furthermore, the relocation of vendors from the central municipal markets to new district markets appears aimed at diminishing the concentrated power of the gremios. Local authorities view the gremios as having political leverage that could threaten their interests, such as by making Santa Cruz less attractive for multinational investment. Business elites and traditional institutions such as the Civic Committee and the regional Chamber of Commerce (CAINCO) share these concerns, perhaps fearing the gremios could form an alternative center of power and a political opposition to their public agenda, which includes departmental autonomy and boosting export trade (Prado et al. 2005). Moreover, the gremios represent large numbers of low-income highland Andeans who seek a foothold in the local economy, but who in some cases are perceived as unwanted outsiders (Andia 2002).

The gremios, in turn, have extended their influence into the formal, representative political sphere of the city of Santa Cruz. First through the figure of Jesús Cahuana, and currently Griselda Muñóz, gremio leaders sit on the Santa Cruz City Council. They may use this influence to negotiate and maintain an economic niche in central urban areas, such as nearby Los Pozos and La Ramada markets. Meanwhile, although they are heavily composed of highland migrants, many of whom are indigenous Quechua and Aymara, the gremios do not seem to be framing their demands based on ethnicity. In this way, the gremios potentially serve as an associational form for collective action that bridges difference through including both migrants and longer-term residents who have also been excluded from formal employment.

By recognizing the relationships between the economic survival of individuals and organizations in the informal economy and urban policies regarding the regulation of land use and commercial activity, city planners and local officials will be better prepared to resolve conflicts over public space. Rather than suppressing informal economic activities, participatory planning strategies may lead to innovative ways to regulate and support these activities, such as those suggested by Griselda Muñóz. 


\section{REVISTA DE ESTUDIOS BOLIVIANOS}

They may also provide common ground in the conflict between seemingly incompatible conceptions of urban public space where these activities take place. This process involves incorporating citizens into policy making and learning from informal workers' perspectives on priorities for change. In the absence of such an approach, the central parts of the city will be zoned and regulated mainly for elites and emptied out of the people whose labor contributes to the building of the city.

\section{Works Cited}

ALBRO, Robert. 2006. "The Culture of Democracy and Bolivia's Indigenous Movements." Critique of Anthropology 26/4 (2006): 387-410.

ANDIA FERNÁNDEZ, José Luis. 2002. "Políticas de mercados y gremiales de La Ramada." Gobernabilidad en Santa Cruz de la Sierra. José Luis Andia Fernández, et al., eds. 23-40. Santa Cruz: SINPA, UAGRM.

ARBONA, Juan. 2000. "The Political Economy of Micro-Enterprise Promotion Policies: Restructuring and Income-Generating Activities in El Alto, Bolivia." PhD. Diss. Cornell University.

ARDAYA, Lorgio. 2007. Personal interview. July 242007.

BENERÍA, Lourdes. 2003. Gender, Development, and Globalization: Economics as If All People Mattered. New York and London: Routledge.

---. and Maria S. Floro. 2006. "Labor Market Informalization, Gender, and Social Protection: Reflections on Poor Urban Households in Bolivia and Ecuador." Gender and Social Policy in a Global Context: Uncovering the Gendered Structure of 'the Social.' Shahra Razavi and Shireen Hassim, eds. Basingstoke: Palgrave Macmillan. 193-216.

---. and Martha Roldán. 1987. The Crossroads of Class and Gender: Industrial Homework, Subcontracting, and Household Dynamics in Mexico City. Chicago, IL: University of Chicago Press.

---. and Susanna Schaller. (n.d.) "Labor Market Informalization and Urban Transformations: A Case Study of Three Bolivian Cities."

BROMLEY, Ray. 1997. "Working in the Streets of Cali, Colombia: Survival Strategy, Necesity, or Unavoidable Evil?" Cities in the Developing World: Issues, Theory and Policy. J. Gugler, ed. Oxford: Oxford University Press. 124-138. 


\section{REVISTA DE ESTUDIOS BOLIVIANOS}

BROWN, Alison, ed. 2006. Contested Space: Street Trading, Public Space and Livelihoods in Developing Cities. Warwickshire, UK: ITDG.

CABRALES BARAJAS, Luis Felipe. 2006. "Gated Communities Are Not the Solution to Urban Insecurity." State of the World's Cities 2006/7. UN-Habitat. London: Earthscan. 146-147.

CAINCO (Cámara de Industria, Comercio, Servicios y Turismo). 2004. Santa Cruz consolida su liderazgo productivo y competitivo en Bolivia. Santa Cruz de la Sierra: CAINCO.

CALDEIRA, Teresa. 2000. City of Walls: Crime, Segregation and Citizenship in São Paulo. Berkeley: University of California Press.

CASTELLS, Manuel. 1989. The Informational City: Information Technology, Economic Restructuring and the Urban-Regional Process. Oxford: Blackwell.

--- and Alejandro Portes. 1989. "World Underneath: The Origins, Dynamics and Effects of the Informal Economy." The Informal Economy: Studies in Advanced and Less Developed Countries. A. Portes, M. Castells, and L.A. Benton, eds. Baltimore and London: Johns Hopkins University Press. 11-40.

CAHUANA, Jesús. 2007. Personal interview. Dec..10 2007.

CODEPO (Consejo de Población). 2004. Estudio de la migración interna en Bolivia. La Paz: Ministerio de Desarrollo Sostenible.

CROSS, John. 1998. Informal Politics: Street Vendors and the State in Mexico City. Palo Alto, CA: Stanford University Press.

DE SOTO, Hernando. 1989. The Other Path: The Invisible Revolution in the Third World. New York: Harper and Row.

ECKSTEIN, Susan. 1983. "Transformation of a 'Revolution from Below'- Bolivia and International Capital." Society and History 25/1 (1983): 105-135.

FAINSTEIN, Susan S. 2006. "Inequality in Global City Regions." The Global City Reader. Neil Brenner and Roger Keil, eds. London and New York: Routledge. 111-117.

GARCÍA PAZ, Ricardo. 2007. Santa Cruz es hermosa pero...Nación Camba. [http://www.nacioncamba.net/articulos/jovenes] downloaded Sept. 15 2010.

GILL, Leslie. 2000. Teetering on the Rim: Global Restructuring, Daily Life, and the Armed Retreat of the Bolivian State. New York: Columbia University Press.

---. 1987. Peasants, Entrepreneurs and Social Change: Frontier Development in Lowland Bolivia. Boulder, CO: Westview. 


\section{REVISTA DE ESTUDIOS BOLIVIANOS}

GMSC (Gobierno Municipal de Santa Cruz de la Sierra). 2004a. Plan de

Ordenamiento Territorial (PLOT). Santa Cruz de la Sierra.

--- 2004b. Ordenanza Municipal para el Uso del Espacio Público. Santa Cruz de la Sierra: Oficialía Mayor de Planificación.

--- 1990. Ordenanza Municipal sobre Políticas Generales de Mercados

Municipales. Santa Cruz de la Sierra: Dirección de Abastecimiento, Construcción de Mercados.

GOLDSTEIN, Daniel. 2004. The Spectacular City: Violence and Performance in Urban Bolivia. Durham and London: Duke University Press.

GUSTAFSON, Bret. 2006. "Spectacles of Autonomy and Crisis: Or, What Bulls and Beauty Queens Have to Do with Regionalism in Eastern Bolivia." Journal of Latin American Anthropology 11/2 (2006): 349-377.

HARDOY, Jorge. 1992. "Theory and Practice of Urban Planning in Europe, 1850-

1930: Its Transfer to Latin America." Rethinking the Latin American City. R. M. Morse and J. E. Hardoy, eds. Washington, D.C.: Woodrow Wilson Center Press. 20-49.

HART, Keith. 1970. "Informal Income Opportunities and Urban Employment in Ghana." Journal of Modern African Studies 11/1 (1970): 61-89.

ILO (International Labor Organization). 1972. Employment, Income and Equality: A Strategy for Increasing Productivity in Kenya. Geneva: ILO.

INE (Instituto Nacional de Estadística). 2001. Censo Nacional de Población y Vivienda. La Paz: INE.

KOHL, Benjamin. 2002. "Stabilizing Neoliberalism in Bolivia: Popular Participation and Privatization." Political Geography 21 (2002): 449-472.

KUDVA, Neema. 2006. "Informality in Urban Space: Spatial Implications and Political Challenges." Rethinking Informalization. Poverty, Precarious Jobs and Social Protection. Neema Kudva and Lourdes Benería, eds. Ithaca, NY: Cornell University Open Access Repository.

[http://www.wiego.org/publications/Rethinking_Informalization.pdf]. downloaded Sept. 152010.

LAZAR, Sian. 2006. "El Alto, Ciudad Rebelde: Organizational Bases for Revolt." Bulletin of Latin American Research 25/2 (2006): 183-199.

LIMPIAS, Víctor Hugo. 2003. Arquitectura y urbanismo en Santa Cruz. Santa Cruz: Universidad Privada de Santa Cruz (UPSA).

MADANIPOUR, Ali. 2003. Public and Private Spaces of the City. London: Routledge. 


\section{REVISTA DE ESTUDIOS BOLIVIANOS}

MARCUSE, Peter. 2006. "Space in the Globalizing City." Global Cities Reader. Neil Brenner and Roger Keil, eds. New York: Routledge. 361-369.

MARRIS, Peter. 1974. Loss and Change. London: Routledge.

MASSEY, Doreen, ed. 1994. Space, Place and Gender. Oxford: Blackwell.

MUÑóZ, Griselda. 2007. Personal interview. August 82007.

OLPADWALA, Porus. 2000. "The Political Economy of the Built Environment."

Design Professionals and the Built Environment. Paul Knox and Peter Ozolins, eds. Chichester, UK: John Wiley and Sons. 11-18.

PALMER, Ronald. 1979. "Politics and Modernization: A Case Study of Santa Cruz, Bolivia." Ph.D Diss. UCLA.

PAP (Programa de Alivio a la Pobreza). 2006. Pobreza urbana: Niveles de incidencia en la ciudad de Santa Cruz de la Sierra. Santa Cruz: Fundación PAP.

PÉREZ SAINZ, Juan Pablo. 2003. "Exclusión laboral en América Latina: viejas y nuevas tendencias." Sociología del Trabajo 47. 107-138.

PNUD (Programa de las Naciones Unidas para el Desarrollo). 2004. Informe de Desarrollo Humano Regional Santa Cruz. La Paz: Plural Editores.

PORTES, Alejandro, M. CASTELLS, and L.A. BENTON, eds. 1989. The Informal Economy: Studies in Advanced and Less Developed Countries. Baltimore and London: Johns Hopkins University Press.

POSTERO, Nancy. 2007. Now We Are Citizens: Indigenous Politics in Postmulticultural Bolivia. Stanford, CA: Stanford University Press.

PRADO, Fernando, et al. 2005. Santa Cruz y su gente. Una visión crítica de su evolución y sus principales tendencias. Santa Cruz: Centro de Estudios para el Desarrollo Urbano y Regional.

RAKOWSKI, Cathy, ed. 1994. Contrapunto: The Informal Sector Debate in Latin America. Albany, NY: State University of New York Press.

ROBERTS, Bryan. 2002. "Citizenship, Social Policy, and Population Change." Exclusion and Engagement: Social Policy in Latin America. Christopher Abel and C. M. Lewis, eds. London: Institute of Latin American Studies, University of London. 111-130.

ROJAS ROSALES, A. 1988. "Mercado laboral y trabajadores por cuenta propia." Santa Cruz: Cuestión urbana y problemática Municipal. Manuel de la Fuente, ed. Santa Cruz: SURPO/Cabildo. 95-111.

ROY, Ananya. 2002. "Marketized? Feminized? Medieval? Urban Governance in an Era of Liberalization." Democratic Governance and Urban Sustainability. 


\section{REVISTA DE ESTUDIOS BOLIVIANOS}

Joseph S. Tulchin, Diana H. Varat, and Blair A. Rubile, eds. Washington, D.C.: Woodrow Wilson International Center for Scholars, Comparative Urban Studies Project. 29-44.

SALEK, Nadine. 2007a. Plan Municipal Nueva Red de Abastecimiento, Mercados y Ambulantes. Santa Cruz de la Sierra, Bolivia: Oficialía Mayor de Planificación. ---. 2007b. Personal interview. July 242007.

SASSEN, Saskia. 1991. The Global City. Princeton, NJ: Princeton University Press.

SOJA, Edward. 2000. Postmetropolis: Critical Studies of Cities and Regions. Oxford: Blackwell.

STEARMAN, Allyn MacLean. 1985. Camba and Kolla: Migration and Development in Santa Cruz, Bolivia. Orlando, FLA: University of Central Florida Press.

UN-Habitat. 2006. State of the World's Cities 2006/7: The Millennium Development Goals and Urban Sustainability. London: Earthscan.

URIOSTE, Miguel, and Cristóbal Kay. 2005. Latifundios, avasallamientos y autonomías. La Reforma Agraria inconclusa en el Oriente. La Paz: Fundación Tierra.

\section{(cc) BY-NC-ND}

This work is licensed under a Creative Commons AttributionNoncommercial-No Derivative Works 3.0 United States License. 